\title{
From the lagoon to the meromictic lake: a case study of lake-bottom sediments of Lake Kislo-Sladkoe (the Karelian Coast of White Sea, Russia)
}

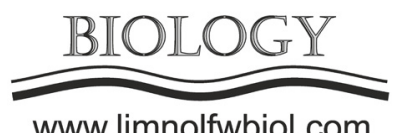

www.limnolfwbiol.com

\author{
Shilova O.S. ${ }^{1 *}$, Leontiev P.A. ${ }^{2}$, Vakhrameeva E.A. ${ }^{3}$, Losyuk G.N. ${ }^{3}$, Grigoriev V.A. ${ }^{4}$, \\ Krasnova E.D. ${ }^{1}$, Repkina T.Yu. ${ }^{1}$, Kublitskiy U.A. ${ }^{2}$ \\ ${ }^{1}$ Lomonosov Moscow State University, Leninskie Gory 1, Moscow, 119991, Russia \\ ${ }^{2}$ Herzen State Pedagogical University of Russia, Nab. Moyki 48, St. Petersburg, 191186, Russia \\ ${ }^{3}$ N. Laverov Federal Center for Integrated Arctic Research Russian Academy of Science (FCIArctic RAS) Severnoi Dviny Emb., 23. , \\ Arkhangelsk, 163000, Russia \\ ${ }^{4}$ St Petersburg University, Moskovsky prospect, 9, Saint-Petersburg, 190031, Russia
}

\begin{abstract}
The distribution of diatoms in the core of bottom sediments of the small meromictic Lake Kislo-Sladkoe on the Karelian Coast of White Sea was studied. The changes in diatom associations in the column show the isolation of the lagoon from the sea and its transformation into a meromictic lake. First alteration of dominant species marks the decrease of hydrodynamic activity as a result of the formation of spit and transformation of the lagoon into semi-closed bay. Second shift in species composition reflects the onset of the strong stratification and occurrence of a bottom anoxic layer.
\end{abstract}

Keywords: diatoms, grain-size, geochemistry, radioisotope dating $\left({ }^{210} \mathrm{~Pb}\right)$, meromictic lakes, lake-bottom sediments, White Sea

\section{Introduction}

Meromictic lakes appear to be one of the stages in the evolution of basins separating from the sea as a result of glacioisostatic uplift of Fennoscandia (Krasnova et al., 2016). The duration of the meromictic stage was estimated to be several hundred years (Subetto et al., 2012). This work was performed as part of a study of diatoms in the bottom sediments of meromictic lakes located in the vicinity of the N.A. Pertsov White Sea Biological Station of Lomonosov Moscow State University. The main tasks of the study are to reveal the changes in diatom associations in bottom sediments during the isolation of basin from the sea and to find signs for different stages of isolation that can be used in paleolimnological studies.

\section{Material and methods}

Lake Kislo-Sladkoe $\left(66^{\circ} 32^{\prime} 54^{\prime \prime} \mathrm{N}, 33^{\circ} 08^{\prime} 05^{\prime \prime} \mathrm{E}\right)$ is situated on the Karelian Coast of White Sea. The lake has a length of $196 \mathrm{~m}$, a width of $147 \mathrm{~m}$ and a maximum depth of $4.2 \mathrm{~m}$. The lake was formed as a result of the isolation of the sea lagoon, separated from the main water area by the island. Seawater enters into the lake only with high tides and storm surges. Freshwater supply is carried out mainly with snow melting. The lake has a desalinated surface layer (mixolimnion) in $0.5 \mathrm{~m}$ thickness, which salinity varies in a wide range (4-28\%o), and a monolimnion with a salinity of 21 $29.5 \%$, separated by a narrow halocline (Krasnova et al., 2016). The upper boundary of the lowermost anoxic layer is unstable (4.0-0.5 m) and experiences both seasonal fluctuations and interannual changes associated with inputs seawater into the lake in winter each 1-3 years.

The Russian corer was used to take the core of bottom sediments from the deepest part of the lake. Diatom analysis, radioisotope dating $\left({ }^{210} \mathrm{~Pb}\right)$, grain-size analysis and determine of $\mathrm{C}_{\text {org }} / \mathrm{N}_{\text {org }}$ ratio were carried out for all $1.5 \mathrm{~m}$ sequence of the sediments (4.19-5.68 $\mathrm{m}$ from water surface).

\section{Results}

According to the data of grain-size analysis the mineral component of upper sediment layers (up to $\sim 4.7 \mathrm{~m}$ ) was presented by silty pelite. Lower there are pelitic silt and sandy-pelitic silt, passing into sand at a depth of $5.44 \mathrm{~m}$. The values of the Corg/Norg ratio varies within a narrow range - from 3.2 to 5.0 suggesting the predominance of autochthonous material in the deposition of organic matter in the bottom sediments of Lake Kislo-Sladkoe. 
A total of 139 taxa were identified at the species level and 23 taxa were identified at the genus level. According to cluster analysis based on the percentage of species three statistically significant diatom zones (DZ) were distinguished. DZ1 $(5.68-4.56 \mathrm{~m})$ covers massive silts and silty sands. Diatoms include marine and brackish-water species: Hyalodiscus scoticus (Kützing) Grunow 1879, Odontella aurita (Lyngbye) C. Agardh 1832, Opephora marina (Gregory) Petit 1888, Rhabdonema minutum Kützing 1844, Grammatophora spp. and others. DZ2 (4.56-4.35 m) coincides with interval of layered silts and gyttja. The main feature of DZ2 is the mass development of small-cell brackishwater species: Cyclotella choctawhatcheeana Prasad 1990 emend. Genkal 2012 in plankton and Pseudostaurosira perminuta (Grunow) Sabbe \& Vyverman 1995, Staurosirella guenter-grassii (Witkowski \& Lange-Bert.) E. Morales, C.E. Wetzel \& Ector 2019 and Nanofrustulum sopotensis (Witkowski \& Lange-Bertalot) E. Morales, C.E. Wetzel \& Ector 2019 in periphyton. DZ3 (4.35$4.20 \mathrm{~m}$ ) includes uppermost part of bottom sediments represented by dark laminated gyttja. Four brackishwater species ( $N$. sopotensis, P. subsalina (Hustedt) E.A. Morales 2005, P. cf. elliptica (Schumann) Edlund, Morales \& Spaulding 2006 and S. guenter-grassii) compose $80-90 \%$ of all valves.

Marine and brackish-water species dominate in DZ1. Freshwater species amount less than $5 \%$ of all valves. The percentage of marine species decreases in DZ2 and DZ3. Excluding Fragilariacea species there are mixed composition of diatoms in DZ2 and DZ3 and clear trend of increasing proportion of freshwater species from bottom to top of sections. The taxonomical diversity of diatoms gradually increases in DZ1 due to appearance a number of motile benthic forms (epipelon). This indicates more favorable conditions for the development of benthic diatoms in a lower hydrodynamic activity (Saburova, 2017). In DZ2 the taxonomic diversity is sharply reduced. This, alongside with the dominance of small-cell forms and the oligodominant character of diatom associations, indicates instability of the conditions and considerable restructuring of communities (Svensson et al., 2014).

According to the data of ${ }^{210} \mathrm{~Pb}$-dating the DZ1/ DZ2 boundary falls on the sixties of the $19^{\text {th }}$ century and he DZ2/DZ3 boundary corresponds to the middle of $20^{\text {th }}$ century. Thus, the stage of semi-closed bay spans about 90 years. The current duration of meromictic lake stage is about 70 years.

\section{Conclusions}

Changes in diatom associations and grain-size of mineral component of sediments in DZ1 indicate a gradual weakening of hydrodynamic activity. The DZ1/ DZ2 boundary shows the most significant alteration in the structure of diatom associations. It is a result of the formation of spit and transformation of the lagoon into semi-closed bay. The boundary DZ2/DZ3, apparently, marks the formation of a more or less stable stratification in the lake. The presence of a desalinated layer is highlighted by changes in the composition of dominants in the group of Fragilariaceae species and an increase in the proportion of freshwater species. A decrease in the concentration of diatoms in the upper part of DZ1 and a decrease in the proportion of planktonic Cyclotella choctawotcheeana can be associated with occurrence of the anoxic bottom layer.

\section{Acknowledgments}

Diatom analyses was carried out on the topic of Government task for Geographical faculty of Lomonosov Moscow State University (GZ AAAA-A16-116032810055-0). The field works and radioisotope dating were realized by support of RFBR (projects 19-05-00966, 19-05-00377 and 19-05-00508).

\section{References}

Krasnova E.D., Voronov D.A., Demidenko N.A. et al. 2016. For inventory of relict basins separated from the White Sea. In: Trudy Belomorskoi biostatsii MGU [Proceedings of the White Sea Biological Station of MSU] 12: 211-241. (in Russian with English summary)

Saburova M.A. 2017. Microphytobenthos. In: Lisitsyn A.P. (Ed.) The White Sea system 4: The processes of sedimentation, geology and history. Moscow, pp. 370-385. (in Russian)

Subetto D.A., Shevchenko V.P., Ludikova A.V. et al. 2012. Chronology of isolation of the Solovetskii archipelago lakes and current rates of lake sedimentation. Doklady Earth Science 446: 1042-1048. https://doi.org/10.1134/ S1028334X12090140

Svensson F., Norberg J., Snoeijs P. 2014. Diatom Cell Size, Coloniality and Motility: Trade-Offs between Temperature, Salinity and Nutrient Supply with Climate Change. PLoS ONE 9(10): e109993. 2014. DOI:10.1371/journal.pone.0109993. 